\title{
Weaving Crafts on Muna Community (A Case Study of the Role of Human Capital and Social Capital in Cultural Reproduction of Weaving at Muna Regency)
}

Jamiludin

Doctoral Student, Department of Sociology, Universitas Negeri Makassar

Rabihatun Idris

Associate Professor, Social Science, Universitas Negeri Makassar

Sulaiman Samad

Associate Professor, Social Science, Universitas Negeri Makassar

\section{Doi:10.5901/mjss.2016.v7n3s1p53}

\section{Abstract}

\begin{abstract}
There were some problems that the researcher formulated in this study. The first was how the functions of human capital as the main actor in reproduction, development, and preservation of the weaving craft in Muna community? The second was how the functions of social capital in building and developing the business relationships of weaving craft in Muna community? This study used a qualitative approach as a research strategy that generates information or data to describe social reality and events related to weavers' lives, history, kinship, and social activities. The main target of this study is to explain or describe the cultural reproduction of weaving craft in Muna community. The data were obtained from 15 informants purposively. The data were obtained through observation and in-depth interviews and were analyzed inductively. There were some results that the researcher found. The first was human capital (knowledge, experience, abilities, skills, creativity, and innovation) as the main actor who affects the reproduction of weaving craft. The quality of manufactured products showed that knowledge and experience combined with the skills created creativity and innovation. The entrepreneur implicated to the increase of quality and quantity of production. The second was the function of social capital from the aspect of trust has been well preserved because of the weaving craftsmen and entrepreneurs consider trust as the most important in business relationships. In the aspect of values and norms, it was necessary to maintain the values and norms in society. In networking aspect, the craftsmen have formed a marketing network in the district, provincial, and also national area.
\end{abstract}

Keywords: Weaving Crafts, Cultural Reproduction, Human Capital, Social Capital

\section{Introduction}

Weaving craft is a form of local wisdom. Local wisdom is defined as a wealth of local culture containing life policies; outlook on life (way of life) which accommodates the policy (wisdom) and the wisdom of life. In Indonesia, local knowledge does not only apply locally on a particular culture or ethnic origin but can be said to be a cross-cultural or cross-ethnic thus forming a national cultural values. For example, almost every local culture in the archipelago, there was a local wisdom that teaches cooperation, tolerance, work ethic, and so on (Suyanto, 2012). Although there was no guarantee that local knowledge would remain the strong face of globalization that offers a lifestyle that is more pragmatic and consumptive. In fact, it can be seen how the local wisdom with policies and philosophies of life barely been implemented in the practice of life that was more pragmatic.

Weaving skills have been known in the Muna area that existed since about 14th century, during the reign of Sugi Manual, the sixth king of Muna. This weaving activity was a form of local wisdom that was still alive and thriving and still maintained by the community. Weaving skill was owned evenly throughout the Muna area. However, nowadays, this skill has been fading away and gradually began to be left by the supporters. Weaving skill was obtained from generation to generation since long time ago, and now, it must be passed down from generation to generation.

Muna weaving craft is one of the local geniuses that have the potential to be developed into an industrial cluster under the coordination of the Department of Economic Enterprises and also Small and Medium Enterprises, Department of Tourism and Creative Economy, Department of Industry and Trade of Southeast Sulawesi and Muna Regency. The 
promotion was repeatedly done to various places (local, national, and international) and weaving craft festivals began to be implemented from 2008 until today. There was the government policy in provincial and district that includes the use of clothing that was made from woven once a week in all government agencies and the private sector. There was also the use of woven garments in official events, but those were used in traditional ceremonies. The government's policy was a fresh breeze for the growth of business opportunities of weaving craft in Muna.

The problem that was often faced in Muna weaving craft as a creative industry was the low quality of human resources. The Head of Department of Economic Enterprises and SMEs in Muna Regency, Madi Joseph disclosed that the main obstacle in weaving craft is the quality of human resources since the average education of craftsmen were only graduated from elementary school or do not complete primary school. There was only a small part who graduated from junior high school and high school. The implication of the education condition of these craftsmen was the low creativity and innovation made by craftsmen, whereas consumer demands require diversification of products to compete with other products of its kind. Therefore, a touch of art from the hands of artisans, creative and innovative motif designers were needed to realize elegant, attractive, and not monotonous works.

Associated with social capital, people who have high social capital include a low rate of crime and the least amount of formal policy, but if the social capital is low, cooperation between people can only take place in the system of laws and regulations formally. High social capital will only be created when there is a strong reciprocity. It means that the interaction is not solely in exchange for calculating, but the combination of altruistic short-term and long-term profit expectations (Syahyuti, 2008). Then the economic value of social capital that can help individuals in a group, for example, to access financial resources, get information, find work, pioneering efforts, and minimize transaction costs (Tonkins, 2000).

The components of social capital should be used for weaving craft entrepreneur in Muna optimally such as trust that was utilized by the individual entrepreneur to build commitment with others in maintaining the cooperation that has existed, the network that was used by individual entrepreneur to gain market, cooperation, supported equipment, and other capital.

Based on the background above, then the problem can be formulated into two formulations. The first was how the function of human capital as the main actor in cultural reproduction of weaving crafts in Muna community? The second was how the function of social capital in developing business relation as a cultural reproduction of weaving crafts in Muna community?

\section{Research Methods}

This research used qualitative research and followed the opinions of Ratna (2004); Chourmain (2008) that social reality is considered as something that is holistic (whole), complex, dynamic, meaningful and interactive relationships.

According to the source, the data extracted can be divided into two kinds, namely primary data and secondary data. Primary data was obtained directly from the field, either through in-depth interviews of woven tool and weaving handloom, traditional leaders, village heads, district, the heads of each department, NGOs, and citizens that were recruited randomly, participant observation, and focused discussion. Secondary data was obtained from the study of literature in the form of books, the work of others or other sources of scientific information that was relevant to the issues in this study.

In order to make this research works according to the plan, this study used some technical tools as research instruments namely the cards of data, interview guidelines and observation guidelines. The cards were used as notes, data categorization, and data classification. Interview guideline was used as a guide in interview progress, and observation guideline was used to facilitate researchers in conducting observations of the research objects. In addition, there were also a photo camera and a video camera to record the observations, and tape recorders to record the interviews

The data analysis applied three stages namely data reduction stage, data representation stage, and data verification stage. While the data validation stage was done by triangulation, observation extension, member checks, and improved persistence.

\section{Research Results and Discussion}

\subsection{Function of Human Capital in Reproduction of Weaving Crafts on Muna Community}

In this section, the researcher would explain the information that was obtained from ten informants about the 
development of weaving crafts in Muna and the function of human capital in reproduction, the development and the preservation of weaving crafts in Muna as the creative economy industry. The analysis of the information that was obtained through interviews related to the human capital. Edwison and Malone (1977) said that "human capitals are the individual knowledge, experience, capability, skill, creativity, innovation." it indicated that human capital was something that owned by a person and it consisted of some aspects namely knowledge, experience, abilities, skills, creativity, and innovation.

\subsubsection{Knowledge Aspect}

Knowledge is one of the factors that influence human activity. Knowledge in this research is that acquired by an individual, whether acquired through formal education, non-formal and informal education that helps a person or group of people in completing their daily work.

The findings of this research showed that knowledge was very efficient in reproduction, development and preservation of the weaving craft as described by the informants. WN explained that her weaving skill was not acquired from formal education, but she gained from informal education. According to WN, when she was ten years old, she began to help her mother. At first, she did the task of rolling up the yarn, and then with her parents, she did stringy activities. At that time, her parents did not give a chance to weave, but secretly she was doing weaving when her mother was not in place. From doing weaving secretly, finally, she got weaving skill slowly but surely began to master and eventually became the independent weaver.

Same as above informant, WI said that weaving skill was acquired from her parent. Her parent gained weaving skill from her grandmother, and so on. In short, WI is a family of weavers, weavers' descent, weaving skill was inherited from generation to generation. In a chance, WI told that she began to weave when attending elementary school, her mother always asked WI to help her stringy after school. The stringy habit was always performed by WI till she finished primary school. After entering junior high school, WI began to weave at any time and replaced her mother. After finishing junior high school, WI began weaving independently despite woven fabric was still made very simple. However, over time, she began to master the weaving skill and then deliver it to her permanent job.

Different with other informants, WR was not born from weavers' family. She said that there were none of her family members who worked as a weaver. Her interest as a weaver began when she approached adolescence (around 15 years old). She visited the house of a neighbor who was weaving, and WR interested in learning to weave instantly. Since that moment, WR learned to weave from neighbors routinely, and she worked as a weaver. At first, she was weaving as a wage laborer and then after feeling sufficient, then she became an independent weaver.

Knowledge is the result of the idea, and this occurs after someone did sensing to a particular object. Sensing occurs through human senses, the sense of sight, hearing, smell, feeling and touching. The most of the human knowledge was obtained through eyes and ears (Notoatmojo, 2007).

According to constructivist approach, knowledge was not the fact of a reality that is being studied, but as a person's cognitive construction of the object, experience, or environment. Knowledge was not something that already available, while others only received it. Knowledge was as a continuous formation by a person who at any time reorganized due to new insights.

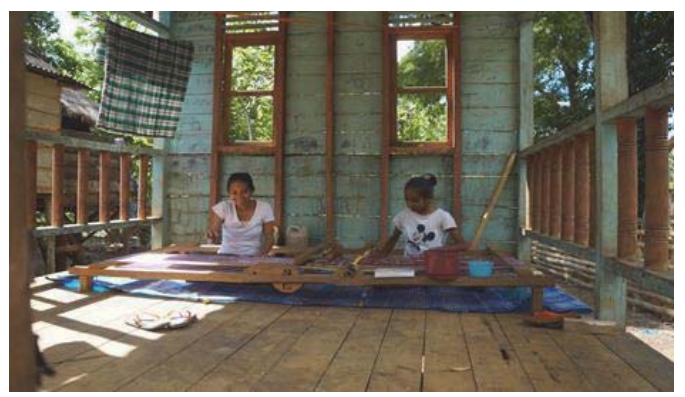

Figure 1. The craftsman was teaching her daughter to do weaving activities

Figure 1 illustrates that the craftsman is assisted by her daughter in the preparation process before she does the weaving activities. It is called "menghani". This process is carried out hereditarily. 


\subsubsection{Experience Aspect}

Human capital theory focused on the individual as the unit of analysis. It is emphasized that employers investment as key attributes (such as education, training, and experience) associated with the competencies and skills that were likely to improve business performance (Becker, 1993). Entrepreneurs with competence and skills were more diverse tend to be effective to regulate and manage the production process and tend to have a more successful business.

Based on the explanation above, the results of this study indicated that the informant WN has occupied weaving crafts since 10 years old and now she was 59 years old, thus the informant has been weaving for 49 years. It was a long and hard experience for a weaver. According to her, many things that have gone through, especially in her job as a weaver that created woven products. According to the informant WN, weaving activities in Muna required patience, persistence, thoroughness and high concentrations. Without those, the yarns that were woven could be broken, motifs that were designed could be broken, and the quality of production was not also optimal and when the process was also getting longer. The experience was certainly one factor that could not be ignored in increasing the number and quality of production. The longer pursue weaving crafts, the more quantity and quality of goods were produced and of course different from the inexperienced.

Experience is the best teacher, that's the classic quote that is often spoken by some people. This quote was also applied to the informant WI. Her experience in occupying Muna weaving crafts for more than 50 years and that was not a short time. she passed a lot of bitter-sweet businesses of weaving craft, but her experience has forge her became a reliable weaver as stated that "I have been weaving since childhood until now, I cannot count anymore how many fabrics that I produce, I can make a variety of motifs, I can design patterns according to the tastes of consumers, all I get because of my long experience."

In line with the information above, WM experienced as a weaver approximately 37 years. She has done the profession as a weaver since 15 years old. A long experience has forged her became a reliable weaver. To develop the weaving skills that have been previously acquired, thus, there was a skill development training that related to the motif design by the Department of Industry and Trade in Muna and other parties (LSM), she always followed. In 2004, the informant followed motif design manufacture training and in 2012 trained to use handloom as a weaving production tool.

Someone's experience in pursuing a job sometimes became a reference to look up how much the person master and expert in a particular field of work. Weaving craft industry needed a special experience to be skilled and proficient in designing motives and conducting new creations.

Studies on the achievement of the human resources quality began to get governments' attention from various countries as happened in the United States. Bates Research (2005) has shown that despite small industry got a large capital to start a business (start-up), but it still failed because it was believed due to lower achievement in specific education and experience based on the field work. It was the reason why the experience was regarded as one of the factors that affect the human capital development of the weaving craft industry in Muna community. The involvement of a person in an occupation or profession in periods or a certain time would improve skills and expertise in the field. The experience aspect can be shown in the figure 2.

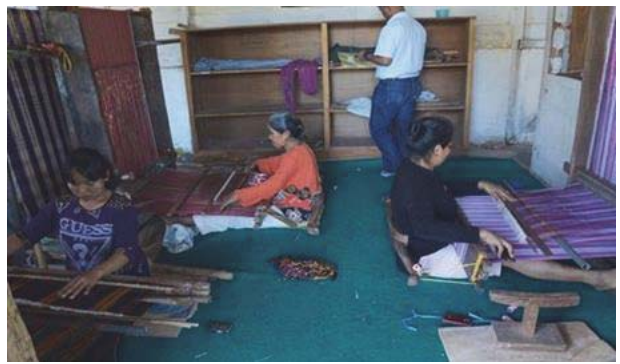

Figure 2. The traditional craftsmen were doing weaving activities

\subsubsection{Capabilities Aspect}

The results of this research indicated that the ability of a weaver acquired through education in the family, in the school environment, and through school education. As stated by the informant WN that the basic ability to weave was obtained from parents, but in providing a motive in woven sarong WN studied it alone. WN said that there was no one motives that 
could not be done. It was easy for example, or see the desired motif, and then WN can directly do it, probably WN was weaver descent, so it was quick to grasp weaving motifs that consumers want.

Besides those mentioned above, one thing that is important in the craft of weaving is a skill aspect because after a person has no knowledge that would be beneficial if they are not skilled in the use of it. Therefore, according to WN, skills in weaving Muna woven fabrics with various motives and yarn types were necessary. There were 16 motifs of Muna woven fabric successfully developed at this time. Each type has its own difficulty level, from the simplest, easy to work and also the most difficult and complicated.

In line with the above informant, informant WT says that weaving skills were acquired from her parent that was passed from generation to generation, not obtained from formal education, because at that time there are no special schools for weavers. According to the informant WT, that to sharp and develop skills in weaving crafts, WT needs much exercise to master the weaving skills. In addition, to develop design ability, WT followed the motif design development training that was organized by the Department of Trade and Industry in Muna. From the results of the training, WT could master how to make woven fabrics in different types and motifs, from the simplest to the most difficult and complex motif.

The results of the interview above showed that the weaving craft in Muna was influenced by the ability of the weavers in their profession as a craftsman. Stokckey (2003) explained that human capital was a concept that described the man in organization and business as a valuable asset and essential to contribute the development and growth as well as physical assets such as machinery and working capital. Attitudes and skills and the ability humans have taken part in the performance and productivity of the organization. Spending on training, development, health and support was an investment.

The description above showed that human capital as other capitals was indispensable to improve the standard and quality of life in many aspects of life, namely in the economic, social, cultural, political and religious. Human capital also referred to the collection of knowledge and skills that inherent to the individual abilities in carrying out the work that created economic objects (Wikipedia 2009).

Related to the ability or competence of Spenser in Anwas (2013), in the individual there were five types of competence. The first type was motifs (motives), competence that related to the ability of individuals consistent and action. The second type was traits (traits), the competence that related to the character or independent character that made individuals do a certain act. This innate trait namely confidence, endurance, and others. The third was the concept of self (self-Concept), competence that related to attitudes and values of the individual. The fourth was knowledge, competence that related to information or knowledge of the individual in certain occupations. The fifth type was skills, the competence of the individual that related to the physical work or mental individual.

\subsubsection{Creativity and Innovation Aspects}

Aspects of creativity and innovation in this study can be interpreted as a process and result of the development and utilization of knowledge, experience, and skills. Those were to create and improve the quality and quantity of production of goods and services that provide significant added value for the welfare of weaver community.

The findings of this study showed that creativity was very influential on the development of the weaving craft in Muna, as stated by the informant WN that creativity became an important element in making the design or motif. The more motifs were created, the more customers of weaving craft were interested. Motif became one of the allure of weaving craft in Muna.

In line with the informant above, informant WT said that creativity in working woven fabric was crucial in weaving craft industry. WT had no doubt in ability and creativity. WT never stopped to create new creations, especially in making the motif design. It was intended to compete with similar products that began to explore the traditional markets. The motif types were "leja, kumbaea, bhia-bhia, samasill", and then the types were developed into several patterns as ordered and the buyers' desire.

In otherwise, the technological innovation by WM was applied as a tool for producing handloom woven fabric. According to WM, there was a significant difference between the products that use handloom and gedokan both in quality and quantity. In quality of production, weaving handloom was more subtle than the production of woven gedokan. In $t$ quantity, the amount of weaving handloom production was more than the production of gedokan. One sheet of fabric was done by using handloom between 1-2 days so that in one month could create between 20-25 pieces of cloth. While 1 sheet of fabric was done by using gedokan between 3-4 days, so in one month can produce between $8-9$ sheets of woven cloth. Similarly, informant $\mathrm{M}$ admitted that if a craftsman wanted to tune its products by consumers, it must be tested to make new creations mainly concerned with the motive. According to $\mathrm{M}$, the advantages of Muna woven fabric and the special characteristic of Muna was "Sobi" weaving (patterned weaving). Meanwhile, other woven fabrics that 
found in Indonesia was not patterned weaving called as flat weaving.

Based on the explanations and interviews with the informants in this study, indicated that the role of human capital in the development and preservation of Muna weaving craft industry was crucial so endlessly from various parties in fostering and developing human resources. Bates (2005) in his research in the United States had proven that although small industry got a large capital (modal) when starting a business (start-up), it still failed because the lower achievement of specific education and experience in business areas. Similarly, a study conducted in a small industry in Indonesia, various forms of financial aid and incentives have been given by the Indonesian government, but all of them have not given encouraging results (Thee, 2006). Although it must be recognized that human capital was believed to have an important role in the economy and business, many studies failed to prove its significance.

Knowledge of Muna weaving was the average that obtained through inheritance from their parents or, in other words, the knowledge they have acquired in the weaving stems from seeing their parents that over time they became smarter. It was because in the area (Muna) there were no special schools to weave. Previously acquired knowledge was deepened through non-formal education, namely training that was organized by various parties, whether it was committed by governments, NGOs, or private parties. According to Suryadi in Damsar (2010), human capital referred to the labor capital that was the holder of capital (capital holders) as reflected in the skills, knowledge, and productivity of a person.

Human capital was a blend of knowledge, experience, ability and skills that created creativity and innovation so that the person or group of people can make creations and innovations as was done by weaving craftsmen in Muna that did not only enhance the quality of goods but also to improve their welfare because the goods / woven that they increase in value of production in terms of both quantity and quality of production.

The following figure 1 presents creativity and innovation aspects in weaving activities. The craftsman has used weaving machine tool.

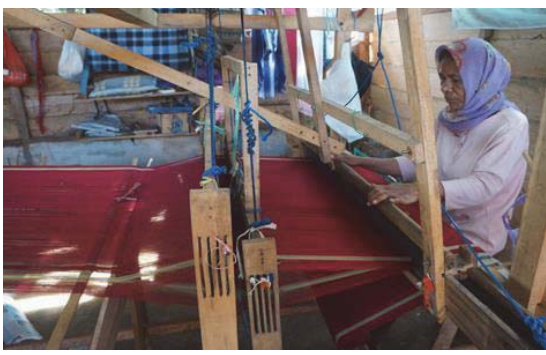

Figure 3. A craftsman was doing weaving activity using weaving machine tool

\subsection{Functions of Social Capital in the Development of Business Network in Cultural Reproduction of Weaving Crafts on Muna community}

Arsyad, et al. (2011) stated that social capital was also a phenomenon that growth from the bottom (bottom-up phenomenon), it was derived from a group of individuals that made up the pattern of the social fabric (social network) that was based on the principle of mutual trust (trust), social reciprocity, action norms, and collective action.

The elements of social capital that were described above became the source of the emergence of interaction among people in a community. The results from these interactions became social capital measurement parameters, such as creating and maintaining trust between the various groups. In addition, such interactions might occur on the scale of individual and institutional. Individually, the interaction occurred through the relationship between individuals and then created the emotional bond between two individuals and in groups. Institutionally, the interaction could be born when the purpose of an organization has in common with other organizations.

To measure these interactions, three parameters of the capital could be used to analyze the results of research. The function of social capital in the development of business relationships and the preservation of the weaving craft in Muna, namely confidence (trust), norms, and networks.

\subsubsection{Trust Aspects}

As explained by Fukuyama (1995), the belief was growing hope in a society that was shown honesty, orderly, and cooperation based on norms.

The results of in-depth interviews that were conducted with WN showed that some aspects must be considered to 
maintain consumer confidence. The first was maintained the quality of woven fabric. The second was the timeliness of processing, if consumers wanted to turnaround time in 3 days then it should be observed. The third was competitive cost. It indicated that should not be too much difference in price with other weavers.

Trust aspect became the main thing in business activities, including weaving craft business. Therefore, according to the informant (interview, August 2015) that for 50 years as a weaver, consumer confidence was a top priority, the principle was customer satisfaction. Trust and customer satisfaction became glue between the weaver and the customer. In producing the woven fabric of customer orders, it was important to fulfill the quality, timeliness jobs and price offers. According to the informant, there has never been a customer, both coming from the Raha city and from outside Muna regency that complains to the woven fabric.

Trust was one of the principal capitals in starting a weaving craft business. This is due to a cultural product should pay attention to the trust aspect of the consumer. WD said that if there were consumers who order woven goods, as far as possible, the goods had a good quality standard, good timelines based on labor agreements.

According to WT, consumer trust was absolute to make her survive as a weaver for more than 60 years. Therefore, customer trust must be the main priority. In addition, the informant also always established mutual trust with itinerant merchants who marketed the woven goods. Trust must be the major capital because the fabrics they take were not usually paid in cash, but sold the goods first and paid them later.

According to the informant $S$, the relation between weaving workers and entrepreneur was created by the relationship of mutual trust and mutual benefit, so that their relationship was not a relationship between the worker and the employer, but the relationship between colleagues. The relationship was created because of the interdependence between the worker and the entrepreneur. The most interesting here was the tools used in weaving were not a business owner, but weavers' private property. Moreover, the process was not only at weaver's home but also business owner's home.

Hasbullah (2006) explained that the trust was a form of willingness to take risks in social relations were based on feeling confident that others will do something as expected and would always act in a pattern of mutual support. Trust became a pillar of strength in social capital. Someone would do anything for the other person if she believed that the person would take her in the direction she wanted. The trust could make a person act as directed by others because she believed that the recommended action of others was a proof of trust given to him. Trust did not appear suddenly. Trust in a person or group of people emerged from the ongoing conditions that happen naturally or conditioned (artificial). The trust could be inherited, but it must be maintained and developed because the trust was not an absolute thing.

In relation to the description above, the level of weavers' trust in Muna could be categorized as criteria for people who had high social capital. That was because the results of interviews with all informants said that they trust with NGOs, economic enterprises, employers, and the government. They had been very concerned about weavers' life without seeing their background where they from.

\subsubsection{Aspects of Values and Norms}

The norms consisted of understandings, values, expectations and goals that were believed and run jointly by a group of people. The norms could be derived from religion, moral guidelines, and standards of secular as well as the ethical code of professional. The norms were built and thrived based on the history of cooperation in the past and implemented to support the climate of cooperation (Putnam, 1993; Fukuyama, 1995). The norms could be a pre-condition and also the product of social trust

Aspects of values or norms of weaving craft became weavers' attention. According to the informant WN, to begin weaving there should be looking for a day and a good time (people in Muna called it kutika), it should not be done at any time, because there was a belief among people in Muna that if it was done at any time, it would cause failure or the results were not optimal. In addition, it was also not allowed if the neighbor was in mourning because the sound of weaving could interfere neighbors who were in mourning. Those were related to values and norms in society.

Norm was always a concern for one informant, the prevailing norm in society was related to business ethics. According to the informant Wl, it was a common habit among weavers to appreciate the weaving work of others or neighbors; they should not give wrong response each other. In addition, according to the informant, in weaving there was aesthetic value and a moral message that must be obeyed by weavers, especially for teenagers. When researchers asked the informant about the moral values in weaving, the informant said that when a girl went home from school, she should be intensified herself to weave as a provision when married in the future and she became calmer when facing problems.

Informant WMb said that norms were embedded in the life of society in general, and the lives of the weavers, in 
particular, were upheld. High work ethos became characteristic of the people in Muna. The spirit of mutual cooperation remains well preserved. Moreover, according to the informant, the norm required that a girl is smart to weave, apparently no longer as tight as in the past, though it was not abandoned entirely.

High and low of values and norms, Sidu (2006) divided it into three criteria. The first criterion was for people who had a minimum social capital / lower among others or often did not obey the religious affiliations. They only obeyed to the values and norms that gave benefit to themselves. They only obeyed the community leaders who had a family relationship. They were less obedient to the outsider or NGOs; they were less obeyed with government regulations. The second criterion was for people who had a basic social capital or just obeying the required course. They obeyed to the values and norms that were agreed by the community and not give risk to them. They obeyed with the community leaders who fight for the interests of families and groups. They obeyed to outsiders or NGO that was already known and fought for interests of the family and group. They obeyed with the government regulations that had to do with the interests of themselves and their group. The third criterion was for people who had a maximum or high social capital. They obeyed all religious things either essential or not, obeyed to the values and norms in general and accommodate the interests of the people, and obeyed to outsiders / NGO that aims to help many people. They also obeyed with regulations that address the interests of the general public without seeing their family, group, tribe, race, and religion.

In the social life, the weavers could not rid themselves from the system of values and norms on Muna community in general or in values and norms, among weavers in Muna regency.

\subsubsection{Network Aspects}

The dynamic infrastructure of social capital networks was cooperation networks among humans (Putnam, 1993). The networks facilitated communication and interaction and also enabled the growth of trust and strengthened cooperation. Healthy communities tend to have strong social networks. People knew and met other people. Then, they build a strong inter-relationship, both formal and informal Putnam (1995) argued that close social networks would strengthen the feeling of cooperation among its members and the benefits of that participation.

Network Aspects according to informants WN, that the network would be created by itself if a weaver gave attention to the quality, accuracy, and competitive prices. Based on the experience so far, the customers would come alone to buy fabrics at her home, both in the form of woven cloth or ordered by yourself based on the desired motif. However, the informant also searched new networks especially sales agents contacted typical fabric of Muna in Raha (Muna regency capital) and Kendari (Southeast Sulawesi provincial capital).

Similarly the previous informant, the next informant said that network did not become a problem for her. According to the informant, based on the experience during 50 years as a weaver, a network formed by itself. Information spread from one consumer to another consumer, so many buyers came at home. Regarding the promotion of the results of woven, the informant was never involved in the promotion of woven results both by the government through the exhibition of development and by the private sector. Thus, the network that was built over the years was a naturally network, not planned, perhaps the outcome would have been different if the network was formed with good planning.

A network according to informants WT has been formed a long ago, because of the sales network was essential for continuity of production. Marketing network always she did on every occasion like visiting Raha (the district capital) or to Kendari (the provincial capital), and she always brings fabrics to be marketed in souvenir outlets. In addition, in order to introduce products of woven were often involved in promotion through establishment exhibition at the district level and the provincial level through the weaving studio "agreed". In addition, the marketing strategy of woven products was buyers come to weaver's home or she sold at her own home, and through middlemen or cooperatives.

The function and role of social capital emphasized the importance of the transformation of social relations and a fragile moment like neighborhood, friendship, kinship into a long-term relationship that was characterized by the obligation to others. Bourdieu (2012) confirmed that the social capital as something related to one another, whether economic, cultural, and other forms of social capital in the form of local institutions and also the wealth of its natural resources.

From the three aspects of social capital, as noted above, how it functions and the role of social capital on business relation aspects to the development of weaving craft in Muna as presented in the previous study. It was evident that there was an influence of social capital on the development and preservation of the weaving craft in Muna.

\section{Conclusion}

The purpose of this study was to investigate how the function of human capital and social capital utilization, in cultural 
reproduction, to develop and preserve the weaving craft in Muna. There were conclusions in this study explained below.

The function of human capital in cultural reproduction of weaving craft on Muna community could be seen from various aspects. It showed that from the aspect of knowledge, almost all informants said that the skill they had as weavers was obtained through inheritance knowledge of their parents, and only small part (one) people learn from neighbors. However, all the weavers learn to weave on an informal basis. From the aspect of experience as a weaver, an average of informants have been working for 20-60 years so that they were able to master all kinds of basic motif woven fabric in Muna. In ability aspects, the average informants were not in doubt to weave because almost all the artisans have been trained related to the diversification patterns and the use of natural dyes. However, there was an obstacle for the weavers in weaving business management issues, even though they have been trained to become entrepreneurs in weaving, but there was still a small part that was able to manage their business well. In terms of skills, the craftsmen have had sufficient skills to become good craftsmen; even so these skills need to be improved in order to face the challenges of an increasingly competitive era. Aspects of creativity among weaving craftsmen apparently became attention to them, it was seen from the birth of new creations in fabrics that they manufacture.

The function of social capital in the development of business networks of cultural reproduction weaving craft in Muna society viewed from three aspects. The first was tryst that indicated the level of trust between the weavers and entrepreneurs, the weaver with the weaver, the weaver with the consumer, and the weavers with the government, NGOs, Cooperative in establishing a high trust. It is not surprising that occurred synergy between the various parties mutually supportive of creating a conducive business climate. The second aspect was the norm that indicated the weavers' attention to the social norms, customs prevailing in society, both between weaver with employers, among weavers, as well as with consumers. The last was networking aspect; the craftsmen indicated that network was necessary. Therefore, the craftsmen continue to strive to maintain the existing network, and establish new networks, so it has now established sales network of the district, namely in Raha and Kota Bau-Bau, Kendari provincial, and national level in Jakarta.

\section{References}

Anwas, Oos M. (2013). Community Empowerment in the Global Era. Bandung: Penerbit Alfabeta.

Arsyad, Lincolin, et al. (2011). Locally-Based Rural Development Strategy. Yogyakarta: STIM/YKPN Yogyakarta.

Bourdieu P. (2013). Arena Cultural Production, a Study of Social Culture. Yogyakarta: Kreasi Wacana.

Chourmain, M.A.S. Imam. (2008). Normative Research for Thesis Writing, Thesis \& Dissertation. Jakarta: Al-Haramain Publishing House.

Damsar, dan Indrayani. (2013). Introduction to Sociology Economy. Jakarta: Kencana Premedia Group.

Fukuyama, Francis. (1995). Trust: The Social Virtues and the Creation of Prosperity. New York: The Free Press.

Onyx, J. (1996). The Measure of Social Capital, paper presented to Australian and New Zealand Third Sector Research Conference on Social Cohesion, Justice and Citizenship: The Role of Voluntary Sector, Victoria University, Wellington.

Fukuyama, F. (1992). The End of History and the Last Man. New York: Free Press. Fukuyama F. (1999). Social Capital and the Global Economy. Foreign Affairs, Vol 74(5), pp.89-97.

Hasbullah, J. (2006). Social Capital: Towards Excellence Human Culture in Indonesia. Jakarta: MR-United Press.

Putnam R. (1995). Bowling Alone: America's e-clining Social Capital. Journal of Democracy.

Putnam. (1993). Making Democracy Work: Civic Traditions in Moder Coleman JS. "Social Capital in the Creation of Human Capital". American Journal of Sociology, Vol. 94(5), pp 95-121.

Ritzer, George., and Goodman, Douglas J. (2007). Modern Sociological Theory. Jakarta: Prenada Media.

Ratna, I Nyoman Kutha. (2004). Theory, Methods and Techniques Research Literature of structuralism poststructuralism Until Narrative Discourse Perspective. Yogyakarta: Pustaka Pelajar.

Syahyuti. (2008). The Role Social Capital in Agricultural Trade. Jurnal Forum Penelitian Agro Ekonomi, Vol. 26(1), pp. 32-43.

Sidu, Dasmin. (2006). Community Empowerment Neighborhood Protected Forest Areas Jompi, Muna Southeast Sulawesi Province, [Unpublished Dissertation], Bogor: Sekolah Pascasarjana Institut Pertanian Bogor.

Spellerberg, Anne. (1997). "Towards a Framework for the Measurement of Social Capital" dalam David Robinson (ed), Social Capital and Policy Development. Wellington: The Institute of Policy Studies, pp. 42-52.

Stockey, Derek. (2003). Human Capital Concept-Definition and Explanation, Google Website on the Human Capital Management Definition.

Suharto, Edi. (2005a). Public Policy Analysis: A Practical Guide Examining Problems and Social Policy. Bandung: Alfabeta.

Suharto, Edi. (2005b). Building Society Empowering People: Strategic Studies Development of Social Welfare and Social Work. Bandung: Refika Aditama.

Thhee, Kian Wie. (2006). Policies for Prifat Sector Development in Indonesia; SME, Promotion Policies for Indonesia, ADBI, Asian Development Bank, Paper No. 26, Published March 2006.

Tonkiss, F. (2000). Trust Social Capital and Economy in F. Tonkiss and A. Pasey (eds) Trust and Civil Society. New York: St. Martin's. 